\title{
The Issues of Track Maintenance Management in Indonesia (Based on Study of the British Railways)
}

\author{
Tetria Yunik Dewi Pamungkas \\ Inspectorate General, Ministry of Transportation, Central Jakarta, INDONESIA \\ tetriayunik@gmail.com
}

Imam Muthohar

Department of Civil and Environmental Engineering, Universitas Gadjah Mada, Yogyakarta, INDONESIA

imam.muthohar@ugm.ac.id

\begin{abstract}
It is believed that there is merit in researching how the management of track maintenance is organized in the United Kingdom, in particular by Network Rail, and then evaluating how this can be applied to the benefit of Indonesian Railways. The purpose of this research was expected to provide recommendations for management improvement of track maintenance by researching the track maintenance management system in Network Rail. This research study is based on secondary data. The analysis was conducted by using comparison method which compares the British Railways management and Indonesia railway management related to track maintenance management. The track maintenance management system was studied by using Network Rail. The results were compared with track maintenance management system in Indonesia. The comparison will provide the data differences that evaluated so the problem can be identified. The final result of this analysis was the identification of problems and improvisation that can be done for the development of track maintenance management in Indonesia. Several management issues have been mapped to several groups: finance management, structure organization, and asset management. From the problems that have been mapped, some improvements are recommended as monopolist authority restriction, maintenance system contract extension, re-structuring organization hierarchy, business plan consideration, track monitoring strategy arrangement, and condition based maintenance strategy adoption.
\end{abstract}

Keywords: Track maintenance management, asset management, British Railways, Network Rail, Indonesian railway.

\section{INTRODUCTION}

The tendency of the problems caused by the high density of population is the availability of land and transportation that will affect the economic development of a country. The better transports give the better economy of the country. With the advantage of transporting large volumes per unit per square kilometer, railway is one of the main transportation required by the country, which have limited land area and high population growth. In addition, the other advantage of using the train is the level of safety which is better than driving on the highway. This gives a positive encouragement for the demand of rail transport. Based on the statistical data issued by BPS (Central Bureau of Statistics) Indonesia (BPS Indonesia, 2014), the number of users of the railway for passengers and freight are fluctuating but still have a tendency to increase from year to year.

Increasing trend of train users provide challenges to regulators and operators to provide better services, especially reducing the level of train accidents. Although a higher level of safety than any other land transportation, but fatalities, loss and delay due to a train accident is a problem that must be minimized.
There are two main problem issues on Indonesian railway. Firstly from the safety issues, most of the causes of the accidents due to the derailment that included in level preconditions for operator acts dominated by technological factors. The above research stated that the technology factor is the biggest problem which one of them is the poor rail condition. Secondly from the business issue, there are demand increase for railway that is pushing the railway system for heavily used and being subjected to increase its capacity. While, there are evidence that the track maintenance regime in Indonesia is inadequate and as a result it is affecting the performance of reliability of the train services. According to the problem issues above, the research purpose were describing and analyzing the problem of track maintenance management in Indonesia based on Network Rail track management and giving several improvements of track maintenance management.

\section{TRACK MAINTENANCE MANAGEMENT}

The requirement of technical terms is a track function, as train guidance and the ability of resistance from vehicles forces through the entire component tracks. Further, the track should be able to 
eliminate the risk of accidents due to track failure such as derailment and track collapse, also the track system must fulfill the requirement of the economic / business point of view that is represented by the convenience and timeliness in which the track should provide a convenient path for passengers and in accordance with the previous design speed. Based on the above requirements, there are several main things that affect performance on the tracks. There are track geometry, track components, track types, measurement of track, and track maintenance (Pamungkas, 2015).

Maintenance management becomes an important point in the industry, especially for transportation industry which reached about $24 \%$ for maintenance cost. It is almost quarter of the total cost which affects significant industry profitability (Haroun \& Duffuaa, 2009). There is not a fully structured of maintenance methodology that universally accepted because the maintenance system designed using experience and judgment which is supported by the formal decision of tools and techniques. The decision strategy and strategic planning in the maintenance system is the main thing that should be considered (Haroun \& Duffuaa, 2009). Besides using the principles of an effective maintenance management system, most of the industry started using asset management system which also includes asset maintenance systems such as the Network Rail (NR). Asset management builds on data from maintenance management activities and provides budgets to maintenance management (Lewis, 2009).

\section{MANAGEMENT OF RAILWAYS IN BRITISH AND INDONESIA}

\subsection{The British Railways (BR)}

The British Railways started with private management (1825-1921), then changed to nationalization management (1948-1980's) and back again with privatization management (1992-2000's) which would reduce government intervention. It provides the opportunity for the company to carry out industry with both business-oriented computation on Rail track and the TOCs (Train Operator Company/s). At the other hand, Bartle (2004) described the privatization of railway industry did not give better achievement except from the reduction of pollution and road congestion. The performance of the train, the efficiency and the safety was decrease with the excess rail capacity at peak hours. This incident then initiated changes to the management system. One of the management reforms is established NR and ORR.
Network Rail established at 2002 as non-profit state company as the owner and operator of Britain's rail infrastructure including maintenance and inspection. NR is responsible for Office of Rail Regulation (ORR) as an independent government organization of rail economy and safety regulator and supervisor. NR enforces several main strategies to improve infrastructure performance which integrated with asset management (Network Rail, 2014).

\subsection{Indonesia Railways}

Train line maintenance based on the Ministerial Decree Number 52 Year 2000 which arrange the maintenance objective, maintenance benchmarking and maintenance process standard. It clarified in Ministerial Regulation Number 67 Year 2012 about Indonesia railway organization, infrastructure performance parameters and infrastructure maintenance activity. Meanwhile, the finance management is based on Ministerial Joint Decrees; there are Ministerial Decree Number 19 in 1999, No.S3/KMK.03/1999, and No.KEP.024/K/03/1999 which explains in details about PSO (Public Service Obligation), IMO (Infrastructure Maintenance \& Operation) and TAC (Track Access Charge). Systems contract between the government and Indonesian Railways (PT. KAI) is a one-year contract system. It was proposed by PT. KAI regarding the value of the PSO, IMO and TAC. The proposal is then reviewed by the government through the ministry of transportation. Once approved, the government made a formal contract with payment schemes 3 months after the implementation of the report by PT. KAI. (Muthohar, et al., 2010).

\section{METHODOLOGY}

The case study took place in Java Indonesia that based on secondary data. The secondary data has carried out from lecture modules, previous research, journal, books and trustworthy website. Informal interviews and discussions were done with personnel from Directorate General of Railway Indonesia. It took to formulate the problem with exploring the current condition of track maintenance management in Indonesia from the government point of view as an owner.

The analysis is done by using comparison method which compares the British railway management and Indonesia railway management related to track maintenance management. It is conducting a study to track maintenance management system by Network Rail. The results were compared with track maintenance management system in Indonesia. The comparison will provide the data differences that 
evaluated so the problem can be identified. The final result of this analysis is the identification of problems and improvisation that can be done for the development of track maintenance management in Indonesia.

\section{ANALYSIS AND DISCUSSION}

The general characteristics differences of Indonesia and British related with railway are shown in Table 1 and Table 2 that describe main differences of British and Indonesia railways.

Table 1.The general characteristics differences of railway between Indonesia and British

\begin{tabular}{|c|c|c|}
\hline Characteristic & $\mathrm{BR}$ & IR \\
\hline $\begin{array}{l}\text { Population density } \\
\text { (densest) (person } / \mathrm{km}^{2} \text { ) }\end{array}$ & 405 & 940 \\
\hline $\begin{array}{l}\text { Current railway } \\
\text { infrastructure } \\
\text { management }\end{array}$ & $\begin{array}{l}\text { Nationalization } \\
\text { of unprofitable } \\
\text { company for } \\
\text { infrastructure }\end{array}$ & $\begin{array}{l}\text { Nationalization } \\
\text { and profitable } \\
\text { state enterprises } \\
\text { collaboration }\end{array}$ \\
\hline Train speed (average) & 40-125 MPh & 40-80 km/hour \\
\hline Track length (total km) & 30,000 & 3,862 \\
\hline Gauge & 1463 & 1067 \\
\hline Amount of track & $\begin{array}{l}\text { Single to double- } \\
\text { double track }\end{array}$ & $\begin{array}{l}\text {-Single to double } \\
\text { track }\end{array}$ \\
\hline Type of ballast track & $\begin{array}{l}\text { Ballast and slab } \\
\text { track }\end{array}$ & Ballast track \\
\hline Signalling & $\begin{array}{l}\text { Track circuit } \\
\text { block signaling }\end{array}$ & $\begin{array}{l}\text { Mechanical } \\
\text { signaling (single } \\
\text { block) }\end{array}$ \\
\hline Power on the track & $\begin{array}{l}\text { Average } 25 \% \\
\text { electrified, less } \\
\text { not-electrified }\end{array}$ & $\begin{array}{l}\text { Most not- } \\
\text { electrified }\end{array}$ \\
\hline Divided route/line & $\begin{array}{l}10 \text { route } \\
\text { utilization } \\
\text { strategy (RUS) }\end{array}$ & $\begin{array}{l}9 \text { DAOP and } 3 \\
\text { Divre }\end{array}$ \\
\hline
\end{tabular}

5.1 Analyses and Identification Problem of Finance Management

In the interest of track maintenance on the railway system, the British government built three departments; there is the Department for Transport (DfT), Network Rail (NR), and the Office of Rail Regulation (ORR). The financing infrastructure management is managed by Network Rail with access charge as primary sources. However, the financing construction of new lines or new technology derived from the system of government grants.

NR is a non-profit organization that is responsible for DFT, while the ORR is an independent organization that is directly responsible to the head of government (ORR, 2014). ORR implements controller functions on train operators and infrastructure operator in both sectors: private (such as the TOCs and FOCs) and the state (such as NR) as illustrated by the red line. The green lines illustrated the flow of finance where the primary maintenance track funding comes from the access charge. The deviation between access charge (income) and the cost of maintenance and operation plus penalties (expenditure) could be the first indication of the performance assessment NR. Minus deviation identified not good performance indicator that gives warning to find the real problem. While other indicator identifies that Network Rail performance is still acceptable.

Table 2.The differences organizer of railway between Indonesia and British

\begin{tabular}{|c|c|c|}
\hline Identification & Indonesia Railway & $\begin{array}{l}\text { British } \\
\text { Railway }\end{array}$ \\
\hline Regulator & MoT & ORR \\
\hline Regulation supervisor & MoT & ORR \\
\hline $\begin{array}{l}\text { Finance (business plan) } \\
\text { supervisor }\end{array}$ & MSOE & ORR \\
\hline Contract system & 1 year & $\begin{array}{l}5 \text { year } \\
\text { (minimum) }\end{array}$ \\
\hline Maintenance funding & MoT & NR \\
\hline Infrastructure owner & $\begin{array}{l}\text { MoT } \\
\text { MoT but handed }\end{array}$ & NR \\
\hline Infrastructure operator & $\begin{array}{l}\text { over to PT KAI with } \\
\text { annual contract } \\
\text { agreement }\end{array}$ & NR \\
\hline $\begin{array}{l}\text { Infrastructure } \\
\text { maintenance }\end{array}$ & $\begin{array}{l}\text { MoT but handed } \\
\text { over to PT KAI with } \\
\text { annual contract } \\
\text { agreement }\end{array}$ & NR \\
\hline $\begin{array}{l}\text { Track testing and } \\
\text { assessment }\end{array}$ & MoT & NR \\
\hline $\begin{array}{l}\text { Asset management } \\
\text { (infrastructure) }\end{array}$ & MoT & NR \\
\hline Maintenance inspection & PT. KAI & NR \\
\hline Renewal & MoT & NR \\
\hline
\end{tabular}

Meanwhile, based on legal regulation (Presidential Regulation Number 53 Year 2012), Indonesian government empower the MoT as the owner of the infrastructure to operate and perform maintenance on it. Currently, the operation and maintenance of infrastructure provided to PT. KAI with the annual contract. The infrastructure financing (referred to IMO) provided by the government. The payment of IMO will be reduced by Access Charge (TAC). The deviation between TAC (income) and The IMO (expenditure) is an annual payment agreement and not based on the infrastructure performance at the time of operation, therefore, it cannot be used as an indication of infrastructure performance assessment and related organizations.

PT. KAI is a profit organization which is responsible for financial management to MSOE and for safety and service to MoT. MoT is a government 
organization as an owner of railway infrastructure and as the controller implements function on train operators and infrastructure operator such as PT. KAI.

According to (Muthohar, et al., 2010) suggest that the PSO, IMO and TAC are not as an independent entity but can only be an aggregate that calculates the net amount. This affects the performance of PT. KAI including declining in the maintenance track performance for each year as a frequent train derailment.

In British Railway chart as shown in Figure 1, the circle shows how the mention of each transaction according to Indonesian Railway, to obtain the clear differences system in British and in Indonesia. The cross circle indicates that the Indonesian financing system does not use the system of franchise contract and penalties. While the other circle shows the similarities between the British and Indonesia system as follows: $\mathrm{PSO} \approx$ subsidy; cost $\approx \mathrm{IMO}$; and Access charge $\approx$ TAC.

First problem is Franchise contract. In Indonesia Railways, there is only one operator companies (PT. KAI) for all route in Java and Sumatra, the government company that is profit-oriented. Thus, the State Company and monopoly system make no funding from the franchise system contract and the absence of competition provide superior properties to the company that will be difficult to establish a standard of fairness and impact on other financing primarily ticket pricing for consumers.

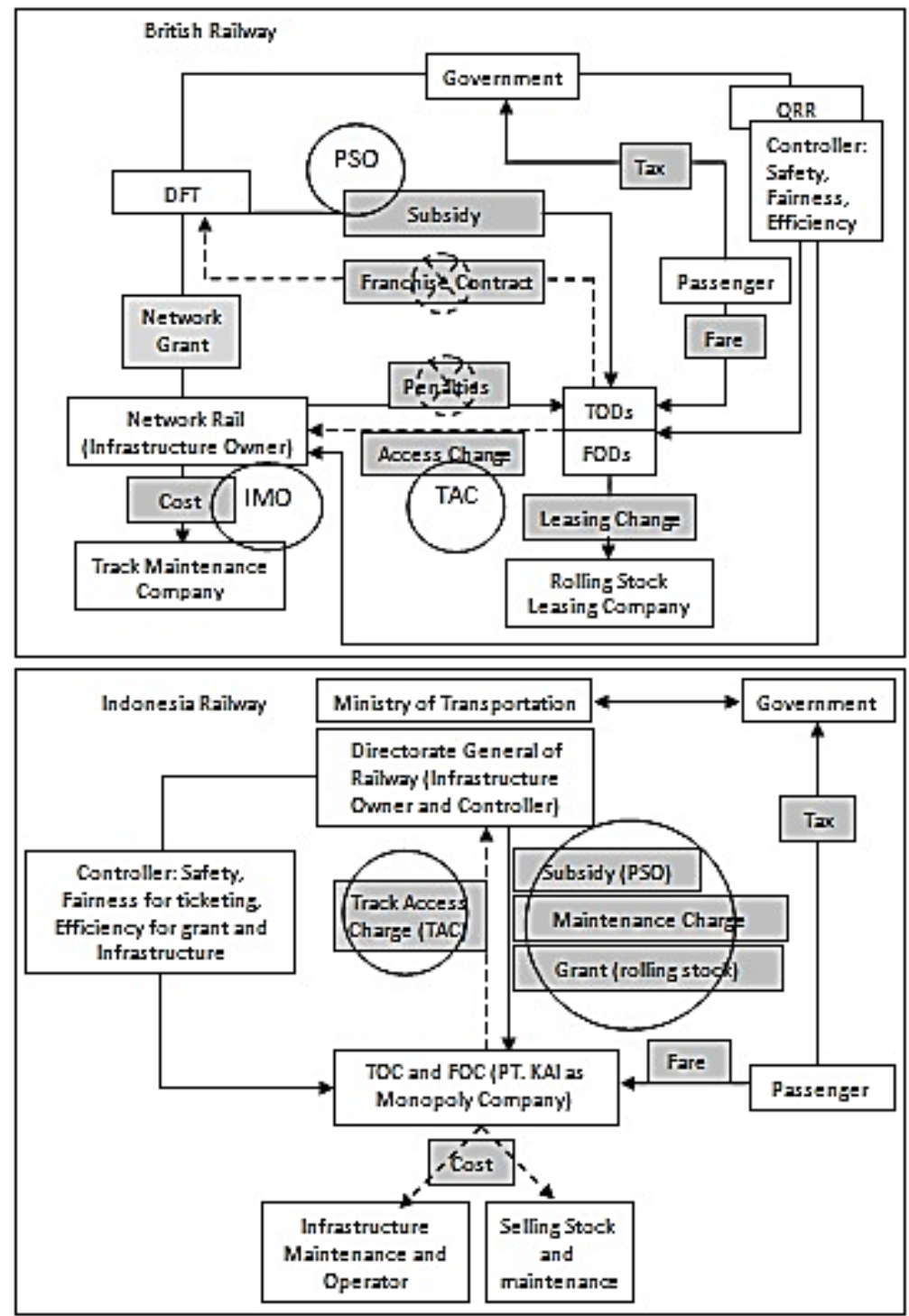

Figure 1.The scheme of the BR and IR financing network 
The second one is the time at contract system of IMO. A system is a one-year contract so the submission, reporting, and evaluation must be done every year. This condition will cause some problems, such as generalizations track conditions without considering location, geography, asset age, and etc; the deferred of maintenance financing due to submission and evaluation is still under discussion, and also there is no opportunity to take account plan to improve maintenance strategy. The last one is penalties systems and company characteristics. Penalties are given to the TOC from NR as a failure compensation infrastructure services (including track) which have resulted in a loss in the TOC so that each party sportive provides the best service. This is the problem of Indonesian railway so that it cannot be applied because of infrastructure maintenance and operations performed by the monopoly TOC (PT. KAI).

NR as a non-profit company has a benchmark to provide the best performance to the user based on public service obligations by the State. Meanwhile, PT. KAI is a state-owned company in the form of profit-oriented that is giving a service with a maximum benefit to the company as its main benchmark.

\subsection{Analyses and identification problem of structure organization}

In the British Railway, the NR's internal policies will be affected directly or indirectly by some stakeholders: TOC / FOC, DFT, RSSB, and ORR. The relation between NR and TOC/FOC is based on business contract. TOC/FOC must pay NR for leasing infrastructure. Therefore, NR should provide infrastructure services according to the term of the contract with fines imposed for NR in case of failure infrastructure that causing losses to the TOC/FOC. DFT is a ministerial government that provides grants to NR. But, the accountability and assessment of the granted usage held by ORR is a government representative. So, there is not a direct relation between NR and DFT from policy or regulation point of view.

RSSB is an independent non-profit company limited by guarantee (non-governmental organization) consisting of British railway stakeholders including NR. RSSB made up of many different organizations that determine the standards in the British Railway industry as the standard technical requirements of products or services to achieve efficiency financing, business performance improvement, and long-term development strategy. RSSB activities include understanding risk, railway standard setting, the management of research and innovation and improvement of cooperation in terms of sustainable improvement strategies. These standards will influence the internal policies NR to achieve a success performance management of track maintenance. It is also used by ORR to determine a benchmark for assessment.

NR is directly regulated by the ORR for NR services performed on the railway, not only as an economic regulator but also as the safety regulator (replacing the Health and Safety Executive (HSE) since 2006). ORR duties are to ensure the railway availability: safe, high-performing and efficient. NR shall provide performance review and funding periodically to ORR and jointly establish further achievement in the relevant control period.

In the Indonesia railway based on the regulation, the responsibility of maintenance, testing, and inspection is similar with the schematic of railway financing as shown in Figure 1. The Ministry of Transportation (MoT) by Directorate General of Railway (DGR) as a regulator and infrastructure owner has a duty to provide facilities for economy class public services as well as providing railway infrastructure and its maintenance (Directorate General of Railway, 2010). Based on the Three Joint Ministerial Decree, infrastructure maintenance and operation, it submitted to PT. KAI. The clear differences of organization between British and Indonesia Railway can be seen in Figure 2 (British Railway chart) with circle that shows the mention of each organization according to Indonesia railways.

The cross circle indicates that the Indonesian system does not have particular train maintenance companies and train leasing companies. While the other circle shows the similarities of management responsibility between the British and Indonesia system as follows: $\mathrm{DfT} \approx \mathrm{MoT} ; \mathrm{NR} \approx \mathrm{DGR}$ (sub-department of MoT); TOCs \& FOCs $\approx \mathrm{PT}$. KAI; and ORR $\approx$ DGR (sub department of MoT).

In Figure 3 describes the separation of management responsibility in MoT and MSOE. Yellow circle is shown that the responsibility of management MOT represented in the sub-department DGR which is similar with management responsibilities by NR and ORR, while MSOE is similar with management responsibilities by DFT. 


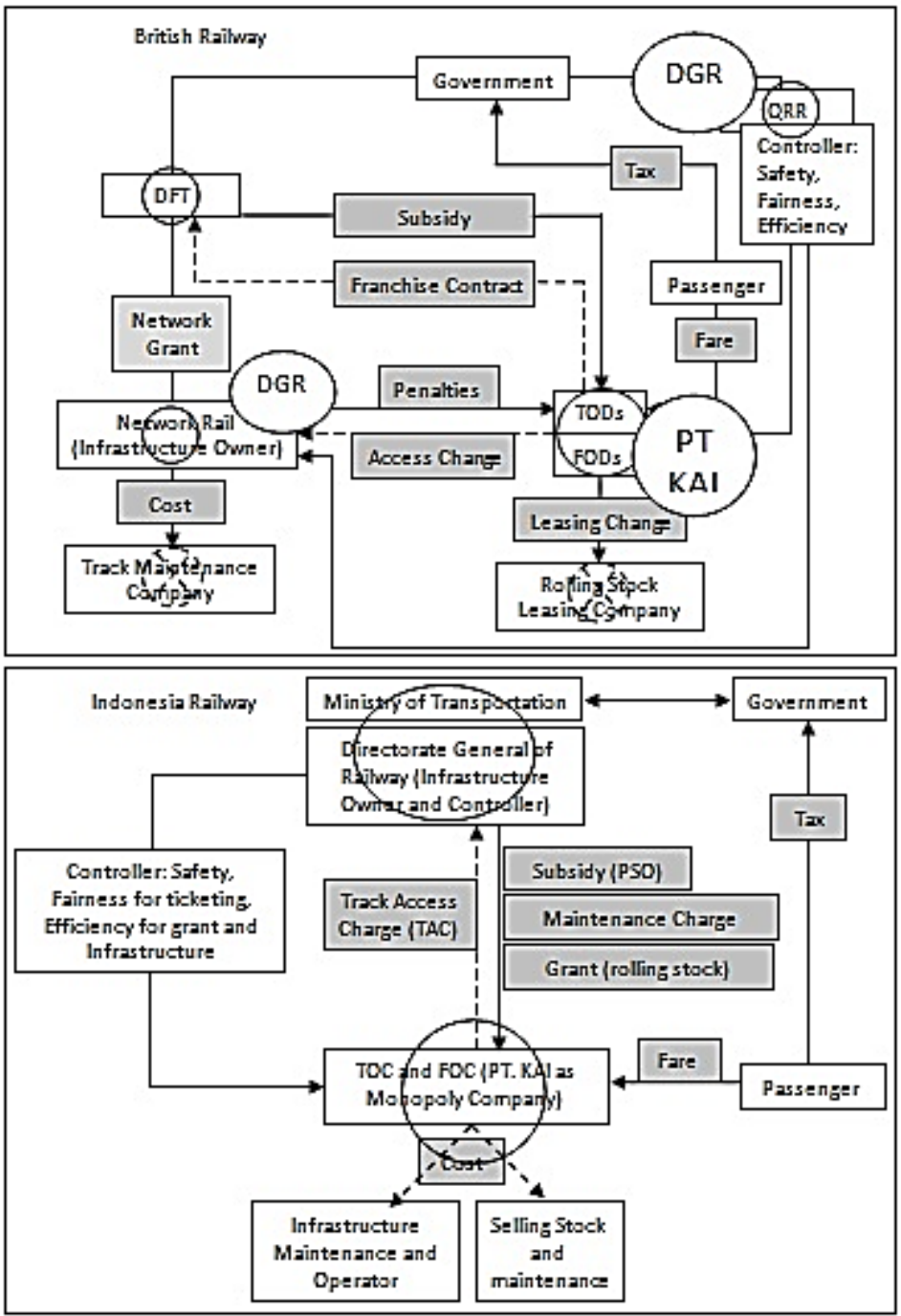

Figure 2.The scheme of the BR and IR structure organization network

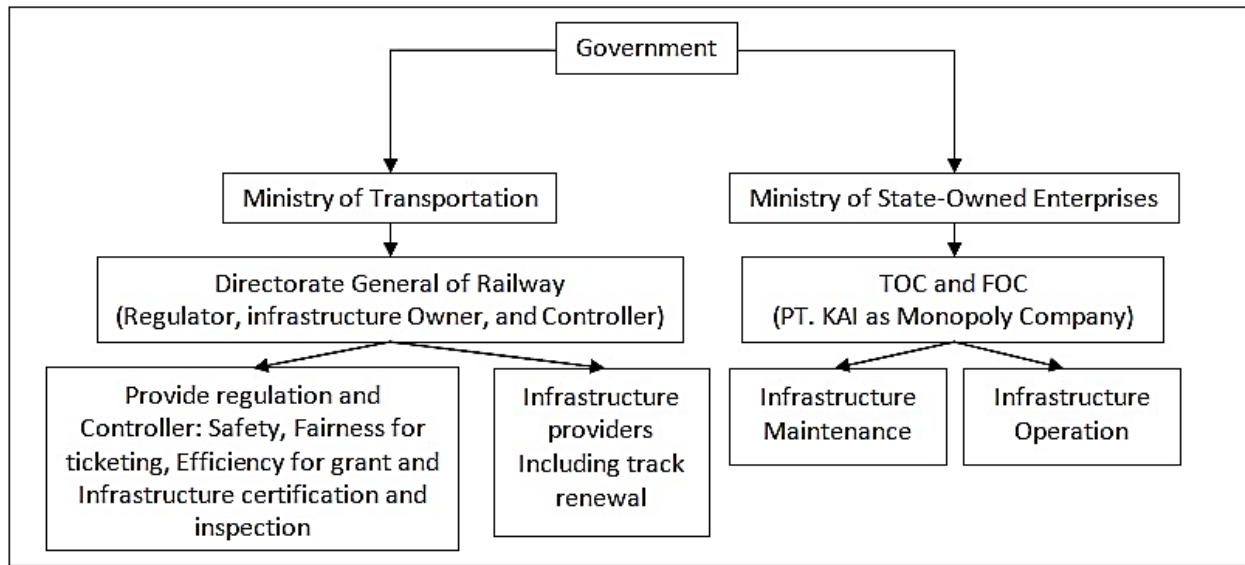

Figure 3.The scheme of infrastructure railway responsibility in Indonesia (MoT, 2011)

The Infrastructure is owned by the DGR (government) as well as operations and maintenance, which is also done by government funding through the State budget. The current maintenance and operational infrastructure however are handed over to
PT. KAI (train operator) with a contract system. So, the ownership is nationalizing regimes while maintenance and operations are privatized regime. The nationalization management creates the state budget expense increase due to maintenance and 
operations along with the additional construction of routes and track length. And, the privatization management creates submission the maintenance to the train operator, risk on the quality of maintenance performed. Maintenance is performed in accordance with the contract or minimizes the maintenance cost to get the maximum benefit.

Indonesian railway regulations for safety and technical are held by DGR under the MoT, while regulations for finance are held by the Minister of State Owned Enterprises (MSOE). There is noindependency for regulator to control the infrastructure: asset, operation and maintenance because the regulator and the owner in one department. And, there is no-integration between safety and economic regulators. Both of these regulations generally contradictory, so it is difficult to find an agreement, not even in a single department an agreement can be reached. In addition, there is no forum whose members stake holders (such as RSSB) to discuss technical standards, management standards, standard of service and standards of assessment as a fair basis of mutual agreement.

\subsection{Analyses and identification problem of asset management}

Using asset management strategy, NR has replaced and upgraded much of the infrastructure and significantly improved the safety and reliability of the railway over the last three years since submitted in October 2002. ORR regulatory, contractual requirements, company strategic business plan are processed by the asset management to be formulated into a policy and used as a benchmark to asset management strategies and objectives including track maintenance and renewal.

According to the research results (Rais, 2008), the annual maintenance volume comparison based on the standard and PT. KAI data reflect the significant differences in the maintenance of rail, due to the corrective maintenance strategy and annual contract system. There is an accumulation of damage from previous years that repairs exceed the standard volume. Although, there is a standard maintenance, in fact, PT. KAI is only doing maintenance on the track with an index above 50 or poor predicated that is only corrective maintenance performed.

Besides inspections carried out by PT. KAI with a value TQI, the government (General Railway) also conducts an inspection for measuring the track performance. Unfortunately, the inspection system of PT. KAI and DGR do not have a clear connection. Therefore the result of the data inspection is not used to optimal which then influences the decision maker of strategy maintenance.

IR does not use the asset management system for track infrastructure so it is difficult to clearly define the business plan, assets policy, asset strategy including its maintenance, renewal, and others. Currently, the infrastructure planning refers to national master plans that concentrate on the development of new routes and capacity while development on an existing asset has not been taken into account such as a track maintenance that's done only in keeping the track functional and is not impaired and kept safe.

The problem of planning is still focused on the cost of construction and not counting the comparison between demand and cost of operation, inspection, maintenance, renewal, and others.

IR uses a testing and inspection as a monitoring process, but currently, it is done only for new track and renewal. The surveys of punctuality and service performed by PT. KAI are the other way for monitoring and benchmarking success. But, the benchmark was in line with ticket prices increasing and restrictions on the number of passengers. The punctuality was based on the suitability of specified GAPEKA or reasonable delay without an increase. While the inspection is carried out by PT. KAI limited to the maintenance that needs to be done in certain areas. All of this show the control and assessment do not refer to the infrastructure reliability.

Management of maintenance is performed by PT, KAI that arranged in contractual agreement. It limited in annual contract, therefore, it refers to the TBM and RBM strategies. The frequency of Time Based Maintenance (TBM) and renewal strategy are based on function of components' age. Although, it has standard maintenance, but in fact, PT. KAI is only doing maintenance on the track with an index above 50 or poor predicated in which only Repair Based Maintenance strategy performed. Consequently, there are accumulations of damage from previous years that make repairs exceed the standard volume.

PT. KAI and DGR perform inspection with different goals but both produce data that can be used in the planning phase. But unfortunately, the inspection system of PT. KAI and GR do not have a clear connection. Therefore the result of the data inspection is not used optimally which then influence the decision maker of strategy maintenance. 
Each issue has been described the advantages and disadvantages which are applied by British and Indonesian Railways as shown from Table 3 to Table 6. The advantages and disadvantages of each finance management problem that have been described, it can be formulated the improvement for Indonesia Railway finance management with eliminating the monopoly system by opening opportunities for other companies who want to join; restrictions monopolise authority through legislation and political policies; changing system maintenance contracts into the multi-years contracts with the evaluation system fixed per-year to ensure uninterrupted maintenance funding; the separation of infrastructure management including maintenance and operation from train operators; the best maintenance for infrastructure must be carried out by non-profit organization; but it needs a sound management with high financial guarantees.

Table 3.The advantages and disadvantages of each finance management system

\begin{tabular}{|c|c|c|}
\hline $\begin{array}{l}\text { Finance Management } \\
\text { Differences }\end{array}$ & Advantages & Disadvantages \\
\hline \multicolumn{3}{|c|}{ Problem 1: Franchise contract } \\
\hline $\begin{array}{l}\text { Multi-operator } \\
\text { (TOC/FOC) }\end{array}$ & $\begin{array}{l}\text { (1) Big funding from track access } \\
\text { (2) Fair competition } \\
\text { (3) Best performance for user }\end{array}$ & $\begin{array}{l}\text { Need better assessment to give the franchise } \\
\text { contract }\end{array}$ \\
\hline $\begin{array}{l}\text { Monopoly (trade } \\
\text { company) }\end{array}$ & No-need assessment & $\begin{array}{l}\text { (1) Less funding from track access } \\
\text { (2) No- competition } \\
\text { (3) No- choice for user }\end{array}$ \\
\hline
\end{tabular}

Problem 2: The time at contract system of IMO

(1) More detailed track conditions

(2) No-deferred of maintenance financing

(3) An opportunity to take account plan to improve maintenance strategy
(4) Better infrastructure performance
(5) Longer useful life of infrastructure component
Multi-years or by own

One-year Low funding for every year
Huge cost at beginning

(1) Generalizations track conditions

(2) The deferred of maintenance financing due to assessment discussion

(3) No opportunity to take account plan to improve maintenance strategy

(4) Short useful life and huge cost for renewal

(5) Low performance of infrastructure

\begin{tabular}{|c|c|c|}
\hline $\begin{array}{l}\text { Penalties to } \\
\text { infrastructure } \\
\text { organizer }\end{array}$ & $\begin{array}{l}\text { (1) Fair playing between infrastructure } \\
\text { organizer and Train operator } \\
\text { (2) Give the best performance }\end{array}$ & $\begin{array}{l}\text { Low performance will take more penalties and } \\
\text { more subsidies }\end{array}$ \\
\hline Non-profit company & $\begin{array}{l}\text { The benchmarking is the best performance for } \\
\text { user }\end{array}$ & Probably low incentive for workers \\
\hline Profitable company & High incentive for workers & $\begin{array}{l}\text { The benchmarking is profit for company not for } \\
\text { user }\end{array}$ \\
\hline
\end{tabular}

Table 4. The advantages and disadvantages of each asset management problem

Problem 9: Inspection connection (between inspection and operator \& maintenance)

Separately organiser Can compare the data

United organiser
(1) Open information

(2) Clear connection $=$ the data used optimal

(3) More effective and efficient
(1) Self-interest $=$ closed information

(2) Unclear connection = the data cannot use optimally

(3) Sometimes overlapping jobs

One source data, cannot compare 
Table 5.The advantages and disadvantages of each structure organization system

\begin{tabular}{|c|c|c|}
\hline Structure Organization Differences & Advantages & Disadvantages \\
\hline \multicolumn{3}{|c|}{ Problem 4: The position of Infrastructure Owner, Operator, and Maintenance } \\
\hline The ownership is Nationalization regime & $\begin{array}{l}\text { Control by government (include } \\
\text { ticket price for the user) }\end{array}$ & Huge cost must pay from State Budget \\
\hline $\begin{array}{l}\text { The operating and maintenance is } \\
\text { privatization regime }\end{array}$ & $\begin{array}{l}\text { Huge cost paid from company } \\
\text { (most from user) }\end{array}$ & $\begin{array}{l}\text { Profitable benchmarking give low } \\
\text { performance for user especially } \\
\text { maintenance }\end{array}$ \\
\hline \multicolumn{3}{|l|}{ Problem 5: Regulator Position } \\
\hline $\begin{array}{l}\text { Independent between regulator and } \\
\text { owner }\end{array}$ & Fair regulation and supervise & $\begin{array}{l}\text { New department means additional } \\
\text { funding/cost and additional experts }\end{array}$ \\
\hline $\begin{array}{l}\text { No independence correlation between } \\
\text { regulator and owner }\end{array}$ & No additional cost & Unfair regulation or unfair \\
\hline $\begin{array}{l}\text { Integration between safety and } \\
\text { economic regulators }\end{array}$ & $\begin{array}{l}\text { Give one benchmarking and give the } \\
\text { best strategy for both }\end{array}$ & $\begin{array}{l}\text { Sometimes it needs hard and long } \\
\text { discussion to decide the priority }\end{array}$ \\
\hline $\begin{array}{l}\text { No integration between safety and } \\
\text { economic regulators }\end{array}$ & Give the best benchmarking from both & $\begin{array}{l}\text { Both regulations generally } \\
\text { contradictory }\end{array}$ \\
\hline Railway Standard board & $\begin{array}{l}\text { Have standard with a fair basis of } \\
\text { mutual agreement }\end{array}$ & $\begin{array}{l}\text { Additional cost or funding for this } \\
\text { organization }\end{array}$ \\
\hline
\end{tabular}

Table 6.The advantages and disadvantages of each asset management system

\begin{tabular}{lcc}
\hline Asset Management Differences & Advantages & Disadvantages \\
\hline Problem 6: Asset financing plan (business plan) & \\
\hline & (1) Counting the benefit and lost from design & $\begin{array}{l}\text { It needs funding for developing asset } \\
\text { management with software to control } \\
\text { Asset financing plan (business } \\
\text { plan) }\end{array}$ \\
$\begin{array}{ll}\text { until maintenance and renewal } \\
\text { infrastructure and collect data. }\end{array}$
\end{tabular}

Problem 7: The system of monitoring and assessing on infrastructure (track) management

Certification benchmarking by Good Worthiness benchmarking for MoT infrastructure operating readiness.

Report from ORR The random inspection sample to prove NR report, more simple and can do for limited person or time

Penalties benchmarking for NR Reliable benchmarking

Benchmarking by PT KAI, (punctuality based on GAPEKA, derailment event)

Problem 8: Maintenance management and strategy

CBM (Condition Based

Maintenance)

TBM (Time Based

Maintenance)

FBM (Failure/correction Based Maintenance)

Multi-years maintenance contract / by owner

Annual maintenance contract
No failure occur

Predictive failure based on component age

Less inspection data $=$ less cost

(1) More detailed track conditions

(2) Prevention of damage accumulation

(3) better infrastructure performance

(4) longer useful life of track component

Low maintenance funding for every year
With manual and limited certified person, it cannot periodic done for all line especially for existing line Sometimes random sample. Cannot give real condition (depend on the quantity of sample)

Cannot do for privatization regime (infrastructure operator and maintenance unite with TOC) Unclear benchmark (it is not clear connection for infrastructure assessment)

Need more inspection data $=$ need more cost

Sometimes the failure occurs before predictive time because of other causes example overload or over speed.

Accident often occur

Huge cost at beginning

(1) Generalizations track conditions

(2) Accumulation of damage

(3) Short useful life of track component

(4) Low performance of infrastructure 


\section{CONCLUSIONS}

British Railways have a fairly complete history of management, started from private regime to nationalization and then changed again to privatization and currently is the success story of public-private cooperation management. So, it is feasible as a standard reference for Indonesia Railway to analyze the problem and find out the improvement.

Several management issues have been mapped to finance management, structure organization, and asset management. The finance management issues described as system monopoly by PT KAI and oneyear contract systems.

The structure organization issues described as the position of owner, operator, and maintainer that is implicating of failure regime of BR history that dependency and no-integrity for regulator and supervisor. The asset management issues described no business plan to set up for the future cost, uncontrolled and non-assessment then refer to the infrastructure reliability, using TBM and RBM as a maintenance and management tool, and no integration of data collection because of unclear connection of inspection system between PT. KAI and DGR.

From the problems that have been mapped above, some improvements are recommended with eliminating the monopoly system or restrictions monopolise authority, changing system maintenance contracts into the multi-years contracts with the evaluation system fixed per-year, separation and clear hierarchy for rail organization, delivering the infrastructure management to a non-profit companyoriented, establishment of management and safety regulators and supervisor under single leadership to facilitate cooperation and integration, separation of the regulator into an independent organization, establishment of RSSB comprising stakeholders, the business plan consideration must be done, track monitoring with suitable strategy of inspection and assessment standard, reducing unnecessary cost by adoption of CBM strategy, adopting the maintenance management strategy by NR.

Nevertheless, the improvements are highly dependent on huge capital, human resources capable and political decision which is the biggest obstacle in Indonesia Railways.

\section{REFERENCES}

Bartle, I., 2004. Britain's Railway Crisis: A Review of The Arguments In Comparative Perspective. Bath: CRI University of Bath.

BPS Indonesia, 2014. Badan Pusat Statistik. [Online] Available at: http://www.bps.go.id/tab sub/view.php?kat=1\&tabel $=1 \&$ daftar $=1 \&$ id_subyek $=12 \&$ notab $=1$

[Accessed 02 June 2014].

Directorate General of Railway, 2010. Rencana Induk Perkerataapian Nasional (RIPNas), Jakarta.

Haroun, A. E. \& Duffuaa, S. O., 2009. Maintenance Organization. In: Handbook of Maintenance Management and Engineering. London: SpringerVerlag London Limited, p. 3.

Lewis, S., 2009. Defining and Understanding the Difference Between Maintenance Management and Asset Management. Annapolis Maryland: AgileAssets, Inc..

MoT, 2011. Bagan Susunan Organisasi di Lingkungan Kementerian Perhubungan Posisi Agustus 2011. [Online]

Available at: dephub.go.id

Muthohar, I., Sumi, T. \& Sutomo, H., 2010. The Implementation and Impacts of PSO, IMO, and TAC Schemes on National Railways Reform in Indonesia. Journal of the Eastern Asia Society for Transportation Studies.

Network Rail, 2014. Network Rail. [Online] Available at: http://www.networkrail.co.uk/ [Accessed 30 August 2014].

ORR, 2014. Office of Rail Regulation. [Online] Available at: http://orr.gov.uk/ [Accessed 30 August 2014].

Pamungkas, T. Y. D., 2015. The Issues Of Track Maintenance Management In Indonesia (based On Study Of The British Railways), Yogyakarta: Master Thesis. Department of Civil and Environmental Engineering. Universitas Gadjah Mada.

Rais, M. Q., 2008. Analisis Volume Pemeliharaan Tahunan Jalan Rel Berdasarkan Passing Tonnage Dan Klasifikasi Jalan Kereta Api (Studi Kasus: Lintas Yogyakarta-Solo), Yogyakarta. 